Article

\title{
Right-Angle Pattern of Minor Fluvial Networks from the Ionian Terraced Belt, Southern Italy: Passive Structural Control or Foreland Bending?
}

\author{
Dario Gioia $^{1, *(\mathbb{D})}$, Marcello Schiattarella ${ }^{2}$ and Salvatore Ivo Giano ${ }^{3, \text { (D) }}$ \\ 1 Istituto per i Beni Archeologici e Monumentali (IBAM), Consiglio Nazionale delle Ricerche, c.da S. Loja, \\ I-85050 Potenza, Italy \\ 2 Dipartimento delle Culture Europee e Mediterranee, Università della Basilicata, Via S. Rocco 3, \\ I-75100 Matera, Italy; marcello.schiattarella@unibas.it \\ 3 Dipartimento di Scienze, Università della Basilicata, Viale dell'Ateneo Lucano 10, I-85100 Potenza, Italy; \\ ivo.giano@unibas.it \\ * Correspondence: dario.gioia@cnr.it; Tel.: +39-0971-427309
}

Received: 14 July 2018; Accepted: 29 August 2018; Published: 3 September 2018

\begin{abstract}
Morphometric analyses of both the topography and drainage network have been carried out in a large sector of the Ionian coastal belt of southern Italy in order to unravel the possible control of Late Quaternary thrust front activity on the evolution of the fluvial net. The study area extends in the southernmost sector of the Bradano Foredeep and is featured by several orders of uplifted marine terraces, ranging in age from Middle Pleistocene to Late Quaternary. The flight of the marine terraces is deeply cut by a trellis-type and regularly spaced minor fluvial network. Morphotectonic investigations based on field survey, photo-aerial interpretation, topographic attributes, morphometric indices, and analysis of longitudinal river profiles suggest a strong control on the drainage network arrangement by a pervasive orthogonal fracture system, produced and preserved into the brittle caprock of the terraces, made by conglomerate. Since a similar pervasive and orthogonal fracture pattern is typically generated by gentle folding of rocks, the development of the Ionian hydrographic networks could be attributed to a general-maybe still active-bending of the foredeep area due to the eastward propagation of blind thrusting of the Apennines orogenic chain.
\end{abstract}

Keywords: morphotectonics; geomorphometry; trellis-type fluvial pattern; structurally controlled streams; ionian coast (southern Italy)

\section{Introduction}

Morphometric analyses of both the topography and drainage network are valuable tools to investigate the influence of tectonic- or eustatic-induced base-level variation on Quaternary evolution of coastal and fluvial landscape [1]. Numerous studies have documented the usefulness of morphotectonic indexes and drainage network metrics for the investigation of the response of landscape to tectonic forcing and crustal deformation in different geodynamic setting [2-7]. In particular, analysis of the drainage network pattern and river profile anomalies is one of the most used approach in decoding the role of crustal deformation in mid- and long-term landscape evolution. It is largely documented that dendritic networks typically occur in regions with little tectonic control, gentle regional slopes, and relatively uniform lithology and a deviation from this kind of drainage pattern is related to the influence of lithological/structural factors or active tectonic processes on the fluvial network configuration [8]. In tectonically active areas, the complex interplay between active and passive tectonic controls can promote the development of "anomalous" drainage network pattern and river 
anomalies, which can be investigated to unravel the role of active tectonics and lithological/structural setting in drainage network evolution $[4,9,10]$.

Morphometric analyses of the drainage network combined with the study of the topographic attributes has been carried out in a large (i.e., about $400 \mathrm{~km}^{2}$ ) part of the Ionian coastal belt of southern Italy in order to provide new constraints about the recent (i.e., Late Quaternary) morphotectonic evolution. The study area includes the southernmost sector of the Bradano Foredeep and is bounded by the front of the south-Apennine chain to the south-west and the edge of the Apulian Foreland to the north-east (Figure 1). 


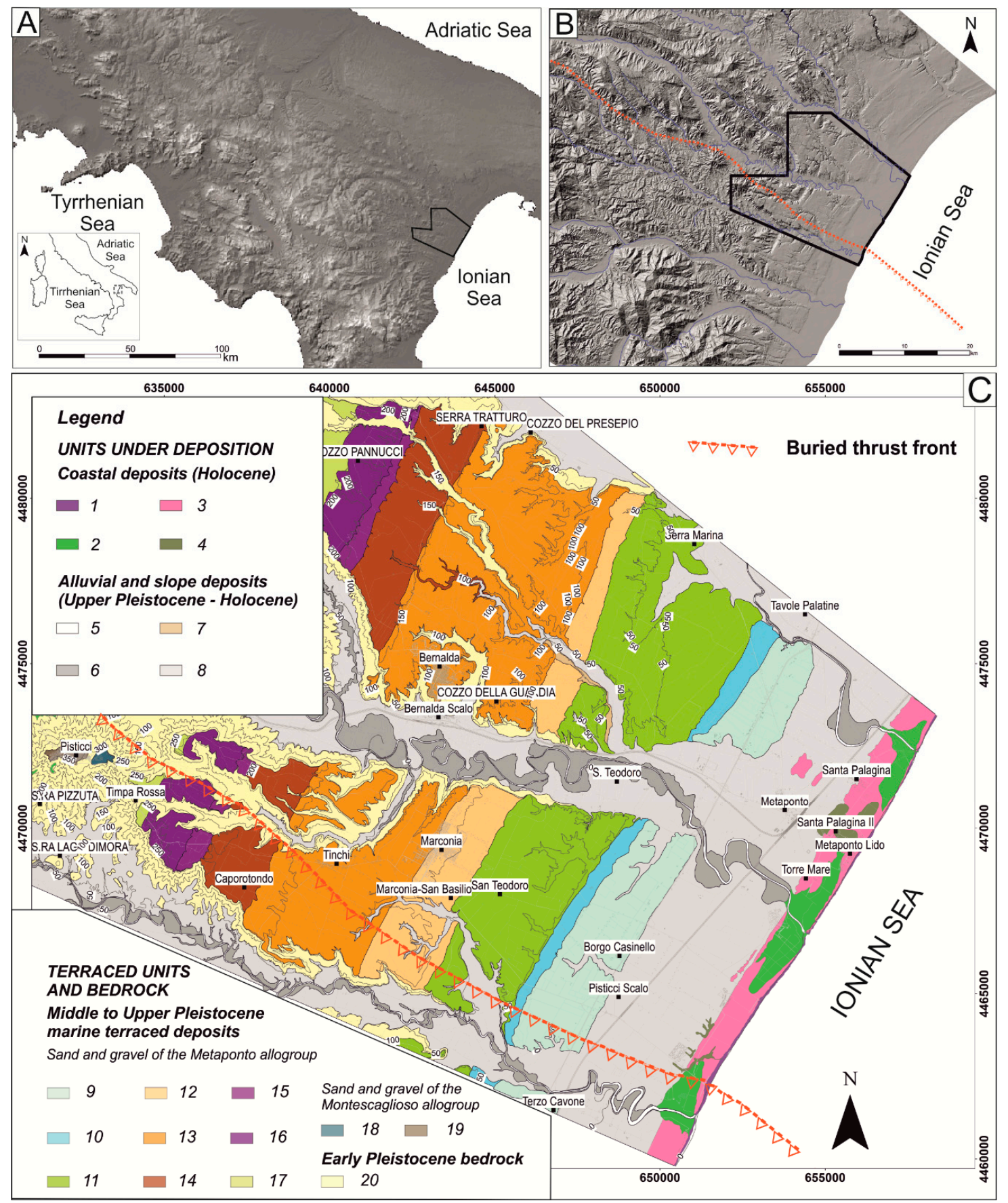

Figure 1. Location of the study area (B) within of the regional framework of the southern Italy (A); (C) lithological map of the study area. (1) Present-day beach/dune deposits; (2) Present-day and relict deltaic deposits deposits (Holocene); (3) Relict dune deposits (Holocene); (4) Palustrine/lacustrine backshore deposits (Late Pleistocene-Holocene); (5) Present-day alluvial deposits; (6) Alluvial deposits (Holocene); (7) Slope deposits (Holocene); (8) Terraced alluvial deposits and coastal plain deposits (Late

Previous works dealing with the tectonic evolution of the study area and surrounding regions are largely based on the reconstruction of the influence of tectonic processes on the plano-altimetric arrangement of marine and fluvial terraces [12-18] but their results provided controversial interpretations in terms of deformation field, fault-related processes and late Quaternary tectonic activity (cf. for example $[13,14,17,19,20])$. 
Pleistocene-Holocene); (9) Scanzano alloformation, Upper Pleistocene; (10) San Teodoro alloformation, Upper Pleistocene; (11) San Basilio alloformation, Upper Pleistocene; (12) Marconia alloformation; Middle-Upper Pleistocene; (13) Bernalda alloformation, Middle Pleistocene; (14) Montalbano alloformation, Middle Pleistocene; (15) Montalbano alloformation, Middle Pleistocene; (16) Gaudella alloformation, Middle Pleistocene; (17) San Leonardo alloformation, Middle Pleistocene; (18) Madonna della Trinità alloformation, Middle Pleistocene; (19) Pisticci alloformation, Middle Pleistocene; (20) Grey-blue marine silty clay (Early Pleistocene). Buried thrust front of the south-Apennine chain comes from [11].

We explore whether morphometric analysis of the drainage network of the study area can furnish new insights about the possible influence of late Quaternary tectonic activity on the planoaltimetric arrangement of fluvial net. Indeed, the drainage network of the study area shows several peculiar features (e.g., trellis-type pattern, right-angle confluences, river profile anomalies and knickpoints), which can suggest the active tectonic control on the development and evolution of the late Quaternary fluvial network.

We calculated statistical properties of the landscape morphology and estimated some geomorphic indices that reflect the interaction between erosional and tectonic processes. Studies on topographic attributes, morphometric indices, and analysis of longitudinal river profiles were integrated with classical (i.e., field survey and photo-aerial interpretation) morphostructural analysis (Figure 2), focused on both the relict and active landforms. Morphotectonic investigations allowed us to provide new constraints on the Late Quaternary evolution of this sector of southern Italy.

\section{Geological and Geomorphological Setting of the Study Area}

The study area is confined between the eastern front of the south-Apennine chain and the western edge of the Apulian Foreland (Figure 1) and represents the southernmost and the youngest outcropping part of the Bradano foredeep [21]. Starting from the end of the Early Pleistocene, the interplay between a moderate tectonic uplift $(<1 \mathrm{~mm} /$ year, [13]) and eustatic sea-level cycles promoted the development of a staircase of marine terraces, which decreases in altitude from $380 \mathrm{~m}$ a.s.l. of the oldest one (MT11, Figure 2) to the about $30 \mathrm{~m}$ a.s.l. of the youngest one (MT1, Figure 2). Depositional coastal wedges related to the different marine terrace orders show homogeneous lithostratigraphical features, being composed by a coarsening upward succession of marine silt, sand, and conglomerate. Surfaces of marine terraces represent the tops of uplifted coastal wedges with an internal complex stratigraphy [22], which have been classified with the criteria of the allostratigraphy [23]. A major unconformity separates the succession in two allogroups, the youngest Metaponto allogroup and the Montescaglioso allogroup (Figure 1). 


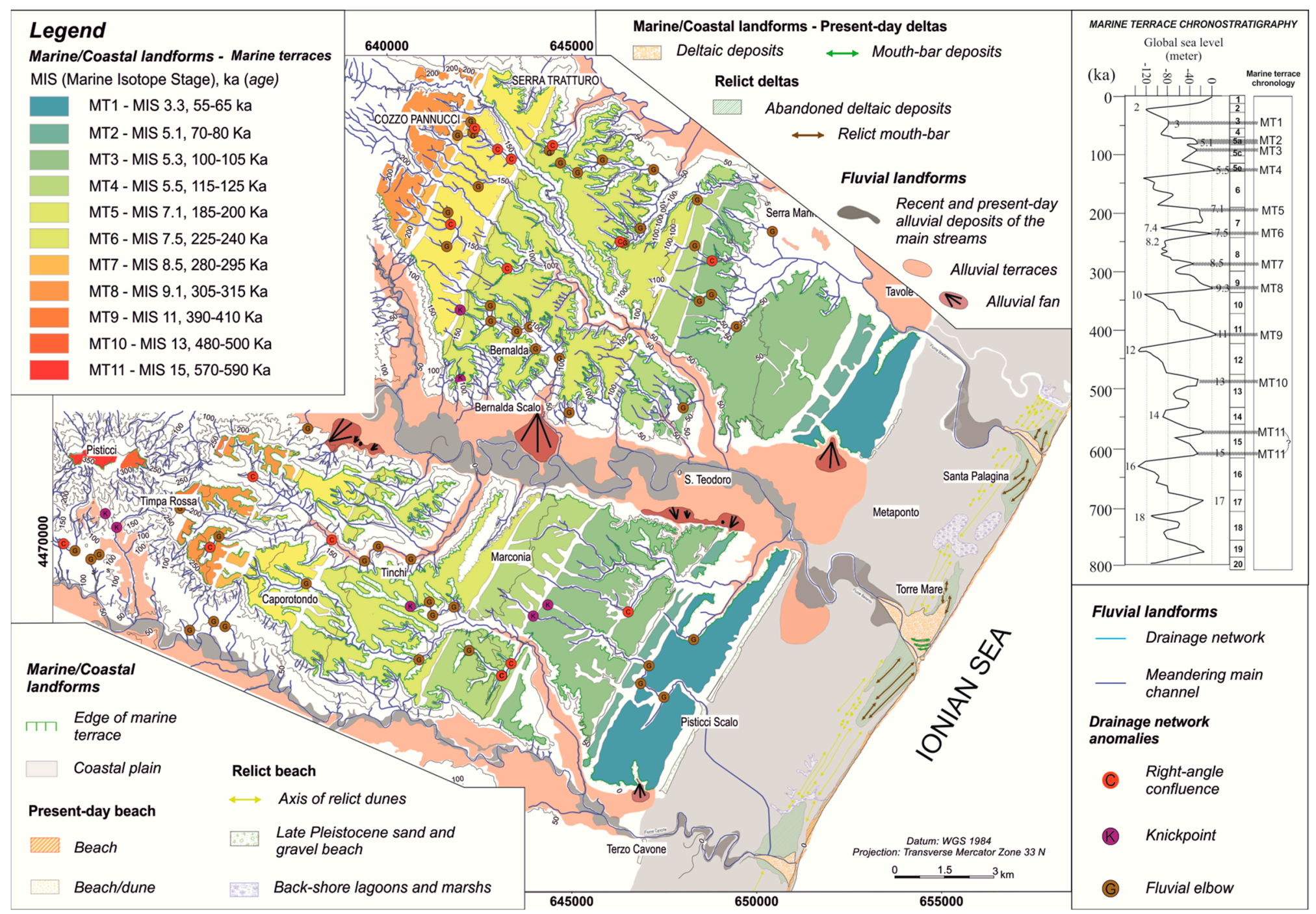

Figure 2. Geomorphological map of the study area and chronostratigraphy of the staircase of marine terraces (mod. after [23,24]). 
These regressive deposits unconformably overlie marine clays of the Argille subappennine Formation [21], Lower Pleistocene in age. Marine clays largely crop out in the south-western sectors of the study area and along the deeper incision of the fluvial net, not far from the present-day base level. The Metaponto coastal plain is a flat depositional surface, partly corresponding to a coastal wedge developed during the MIS 3 highstand. [11-13,22]. Fast base-level fall and related incision processes of the Last Glacial Maximum promoted the aggradation and progradation of continental and transitional deposits, which have filled the LGM palaeotopography. Youngest deposits of the study are alluvial environments, either located along the channels of the main rivers or on wide flood plains, whereas transitional deposits belong to delta and beach environments, whose depositional systems, during the late Holocene, prograded up to the present-day shoreline [11]. Until the land reclamation of the last century, the backshore area of the Metaponto coastal plain was characterized by the presence of wide limno-palustrine environments. The plain is now represented by sandy and silty meandering fluvial systems, with several artificial channels. Low-altitude areas of the coastal plain are still subject to occasional flooding along the main streams during major rainfall events [25].

Seismotectonic analysis based on the spatial and vertical arrangement of northern Calabria and Basilicata marine terrace staircase revealed a regional shortening and a contractional tectonic regime during Middle-Late Pleistocene times and possible evidences of Holocene active deformation and seismogenic potential [13,14]. However, some authors [11] have suggested that the uplift and dissection of the marine terraces might be attributed to the erosional processes triggered by Middle-Late Pleistocene isostatic rebound rather than active crustal deformation.

\section{Materials and Methods}

Quaternary tectonic processes exert a strong influence on the landscape features and drainage network arrangement and morphometric analysis of landscape elements can frequently provide key information on characters and rates of recent deformation (see for example [1]). In this paper, morphotectonic analyses have been firstly focused on the individuation of the drainage network anomalies (i.e., right-angle confluences, fluvial elbows, knickpoints and knickzones) through a traditional approach based on the integration of field geomorphological survey and photo-aerial interpretation. Then, we have performed a quantitative analysis of both topography and drainage network aimed to the extraction of several indexes and metrics, which have been used to investigate the possible influence of active or recent (i.e., Late Quaternary) tectonics on the configuration of the fluvial network. Topographic analyses are based on the systematic extraction of topographic swath profiles whereas the study of the drainage network includes both the quantitative investigation of the spatial distribution and preferential orientation of the channels and analysis of river longitudinal profiles. Extraction of morphometric features is supported by the processing of a high-resolution (i.e., spatial resolution of $5 \mathrm{~m}$ ) DEM deriving by LIDAR data [26]. Comparison between this dataset and other mid-resolution DEMs (for example, the $30 \mathrm{~m}$ ASTER DEM, see also [27]) suggests a high degree of accuracy and quality of our DEM, which provides the better results in the extraction of topographic data of the study area.

Integrated analysis of drainage network pattern, preferential orientation of channels and spatial distribution of fluvial anomalies has been used to infer the possible control of Late Quaternary tectonic bending related to the latest contractional stage of the southern Apennines on the recent drainage basin development and evolution. Such a methodological approach represents one of the most effective to unravel the occurrence and rate of long- and short-term crustal deformation in different geodynamic setting [7,28-32], amongst others.

\subsection{Swath Profiles}

Topographic swath profiles are constructed by extracting the maximum, minimum and mean altitude within a more or less wide strip and are here used to capture the topographic pattern on a regional or sub-regional scale and to investigate the possible influence of Quaternary or recent tectonic 
phenomena on landscape arrangement. Variation along the swath of derivative parameters such as local relief and hypsometric integral has been also estimated in order to acquire additional information about the degree of dissection of the landscape. In this work, we have extracted 5 profiles with a $500 \mathrm{~m}$-wide swath along two main and roughly perpendicular orientations (Figure 3). Topographic data are extracted by the $5 \mathrm{~m}$ DEM using a dedicated ArcGis tool able to construct curvilinear swath profiles (i.e., the SwathProfiler tool, [33]). Profiles 1 and 2 follow the regional slope of the marine terraces whereas the other ones are traced along a curved strip intersecting the MT3, MT4 and MT6 terrace orders.

\subsection{Analysis of Fluvial Net Pattern and Azimuthal Analysis of Minor Streams}

Drainage network of the study area has been extracted in a GIS environment using topographic maps and ortophotos at a 1:10,000 scale. All the mapped channels have been classified according to the Strahler's hierarchical scheme [34] and their azimuthal orientation has been derived by an automatic procedure in ArcGIS. Apart from a simple frequency-weighted statistical analysis of the different orders of channel orientation data, we have re-processed the azimuthal data of channels after the subdivision of each channel in segment of $250 \mathrm{~m}$ (length-weighted rose diagram). Moreover, rose diagrams for areas with similar lithological features and for homogeneous values of concavity index (see Par. 2.3) have been constructed in order to infer the possible relationships between stream arrangement, lithology and degree of landscape dissection. Moreover, a density map of the drainage network has been constructed using a spatial analysis tool in Arcgis that calculates the line density (units of length of channel per unit of area) within a square moving windows of $500 \mathrm{~m}$. The map can furnish reliable information about the pattern of drainage network and can represent a quantitative measurement of the degree of regular spacing of channels in the different sectors of the study area.

\subsection{River Profile Analysis}

Many works have demonstrated that analysis of river longitudinal profiles can be a powerful tool to extract the occurrence and modalities of uplift and crustal deformation at different temporal and spatial scales [30,35-40]. These studies are largely based on the analysis of the spatial distribution of channel metrics able to estimate the deviation of the river longitudinal profiles to the "graded" form (see for example [41-43]). In this paper, river profile analysis has been carried out according to the methods and procedures developed by $[44,45]$. We have extracted the channel elevations and upstream drainage areas from the $5 \mathrm{~m}$ DEM using the Stream Profiler tool. Stream profile analysis is based on the fit of a linear regression in a log-log slope-area graph, which allowed us to extrapolate the concavity index (the slope of the regression) and the steepness index (the y-intercept, that is the projection of the best-fit line that intersects the y-axis). A map of the normalized steepness index (ksn) with a reference concavity index of $\theta_{\text {ref }}=0.45$ has been also drawn. Ksn map allowed us to perform an effective comparison of river profiles with very different drainage area and different concavity indices [45]. It has been argued that transient and steady-state bedrock rivers showed a non-linear relationship between channel steepness index and uplift rate ([44-46], among others) and spatial distribution of ksn values can be useful to individuate the sectors of the landscape featured by abrupt changes in river profile shape, knickpoints and knickzones of tectonic or lithological origin ([1] and references therein). 

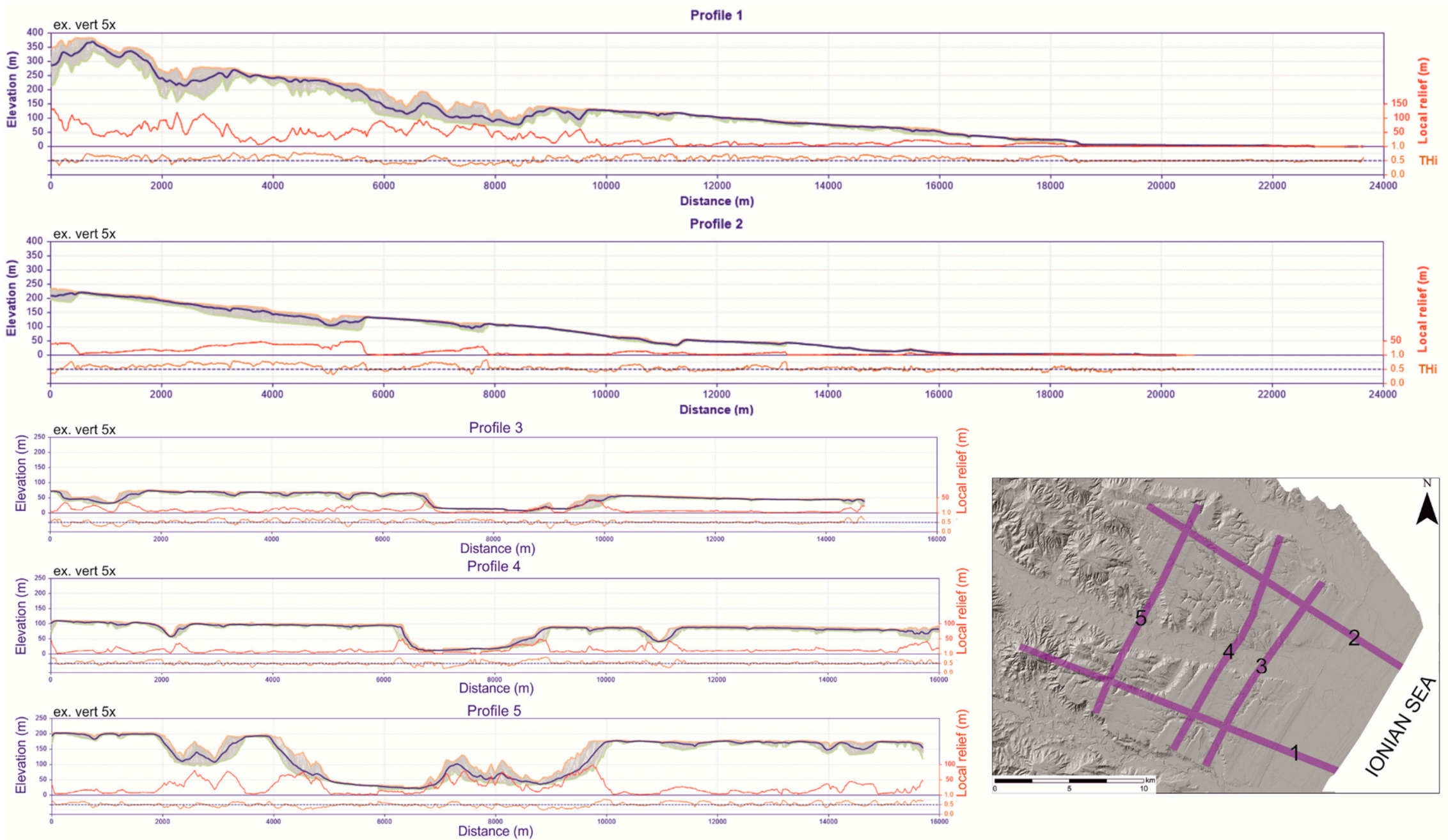

Figure 3. Swath profiles (width of $500 \mathrm{~m}$ ) extracted transversally and longitudinally to the staircase of the marine terraces by using a $5 \mathrm{~m}$ DEM. Transverse Hypsometric Integral (THi, [33]) is estimated through the normalization of the hypsometric integral by the local relief. 
In addition, several morphometric indexes of the longitudinal normalized river profiles (sensu [47]) such as concavity (C), maximum concavity (Cmax) and length of maximum concavity (Lmax) have been estimated for each channel of the study area. The normalization of the river profile allows the direct comparison of rivers with different length, hierarchic order and slope and the normalized concavity (C) represents the area below or above a straight line in a normalized distance-normalized elevation graph. Concave normalized profile show a negative value of $C$ whereas positive values indicate a convex shape of the river normalized profile. Maximum concavity $(\mathrm{Cmax})$ and length of maximum concavity (Lmax) are the point of the highest values of concavity on the y-axis (i.e., normalized elevation) and $x$-axis (i.e., normalized distance), respectively.

Such estimations have been carried out using the NProfiler tool [33] and have provided additional information about the deviation from the equilibrium state (i.e., transient vs. graded) of channel reaches. All these metrics have been statistically combined to the channel orientation data in order to investigate the possible correlation between the preferential orientation of tectonically-controlled streams and their history of morphoevolution.

\section{Results}

\subsection{Morphotectonic Analysis and Swath Profiles}

The landscape of the study area is featured by a gently-dipping staircase of marine terraces, repeatedly interrupted by morphological scarps roughly parallel to the present coast-line (Figure 2). Marine terraces are deeply cut by a minor drainage network, which shows a well-defined trellis-type pattern and represents the tributary valleys of the three main rivers (i.e., Bradano, Basento, and Cavone rivers). These main streams are meandering-type channels with large alluvial plains, which transversally crossed the marine terrace staircase in the lower reaches and the wide Metaponto coastal plain in their lowest courses. Morphotectonic analysis has been focused on the individuation of all the fluvial network anomalies representing a geomorphological evidence of a possible active or passive tectonic control on the evolution of the fluvial net. These morphotectonic signatures include the anomalous or right-angle confluences, knickpoints or knickzones and fluvial elbows. Widespread occurrence of these geomorphic elements (Figure 2) suggest a drainage network that deviates from a typical pattern of low structurally-controlled areas. Indeed, a sub-dendritic pattern of the fluvial net can be only recognized in the south-westernmost sectors of the study area, where silty-clay marine deposits largely crop out. A visual inspection of the fluvial network anomalies indicates a "pervasive" and homogeneous distribution of these elements, which are mainly located along the deeper incision of the different orders of marine terraces. Trellis or angular drainage pattern with a NW-SE and NE-SW trend can be clearly observed in these sectors, which are mainly carved in conglomerates of the Metaponto allogroup (cf. Figures 1 and 2).

Swath profiles of Figure 3 can be useful to estimate the mean topographic features of the landscape and its degree of fluvial dissection in the different sectors of the study area. Indeed, profiles 1 and 2 show the general gradient of the landscape, which shows higher roughness and higher values of local relief in the north-westernmost sectors of the study area. In particular, values of the local relief higher than $100 \mathrm{~m}$ occur where the swath profile 1 crossed the oldest marine terraces (Figure 3). In addition, the low relief of the south-eastern sector of the study area can be clearly observed. Mid altitude areas show a minor degree of landscape dissection and local relief are generally distributed on values lower than $50 \mathrm{~m}$.

\subsection{Drainage Network Pattern}

The staircase of terraces of the study area is deeply cut by a minor drainage network, which is mainly developed according to a trellis pattern (Figure 4), especially where sand and conglomerate of the marine coastal wedges crop out. The drainage network is more developed and arranged in a 
radial to sub-dendritic scheme only in the southwestern sector of the study area, where marine silty clay largely crop out.

Additional information about the spatial distribution of the channels has been extracted by the drainage density map of Figure 5.

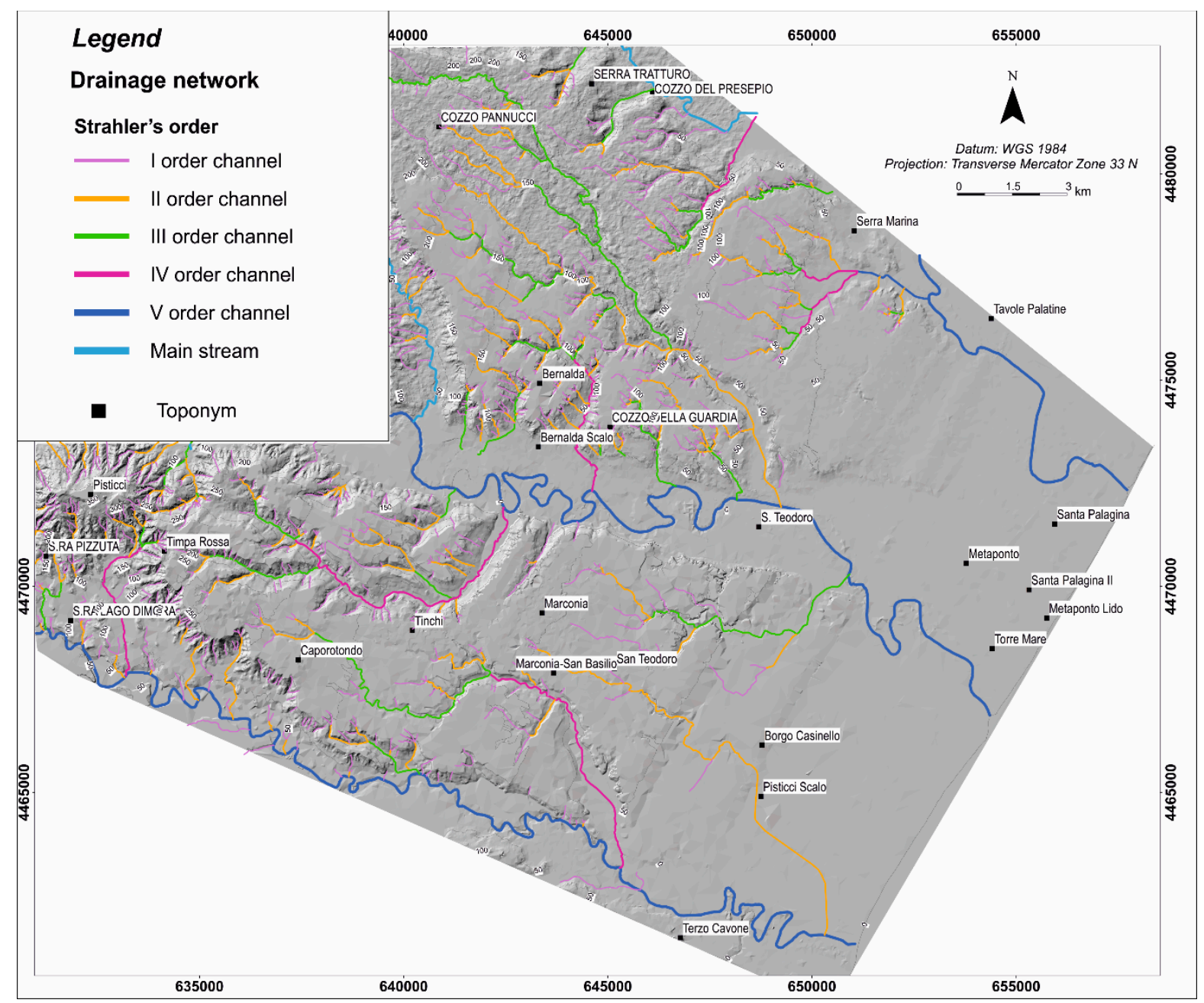

Figure 4. Drainage network of the study area. Channels are portrayed on a hillshade deriving by the $5 \mathrm{~m}$ DEM.

Profiles 3, 4 and 5 run along the same orders of marine terraces and can be useful to detect the total amount of fluvial incision of the main stream of the area (i.e., the Bradano River, see Figure 2). Values range from about $50 \mathrm{~m}$ for the MT3 terrace (see Profile 3 of Figure 3) to about $160 \mathrm{~m}$ for the MT6 terrace. Moreover, regular spacing of minor fluvial incision and a subtle trend of decrease of the mean altitude toward the north-east can be recognized in the three swath profiles (Figure 3).

The map shows the highest values of the drainage density map in the south-western and central sectors of the study area. Apart from the high density of channels in the south-westernmost clay-rich areas, the northern sector (i.e., the left orographic side of the Basento River) is featured by higher concentration of drainage than the southern one. Spatial distribution of drainage density shows a notable elongation of maxima along two main trends (i.e., NE-SW and NW-SE orientation) and a regular spacing of the areas of high concentration of the drainage density.

Frequency-weighted rose diagrams of the channels of different Strahler's order (Figure 6) highlight several preferential orientations of the fluvial net. First order (I) channels show a clear maximum according to the $\mathrm{N} 120-140^{\circ}$ trend and a minor peak along the NE-SW trend with a high statistical 
dispersion. Rose diagrams of the second (II) and third (III) order channels show a minor statistical dispersion and the WNW-ESE and NE-SW trends appear more statistically significant. In particular, II order channels are preferentially arranged along the N 30-40 trend whereas the E-W orientation is also present in III order channels.

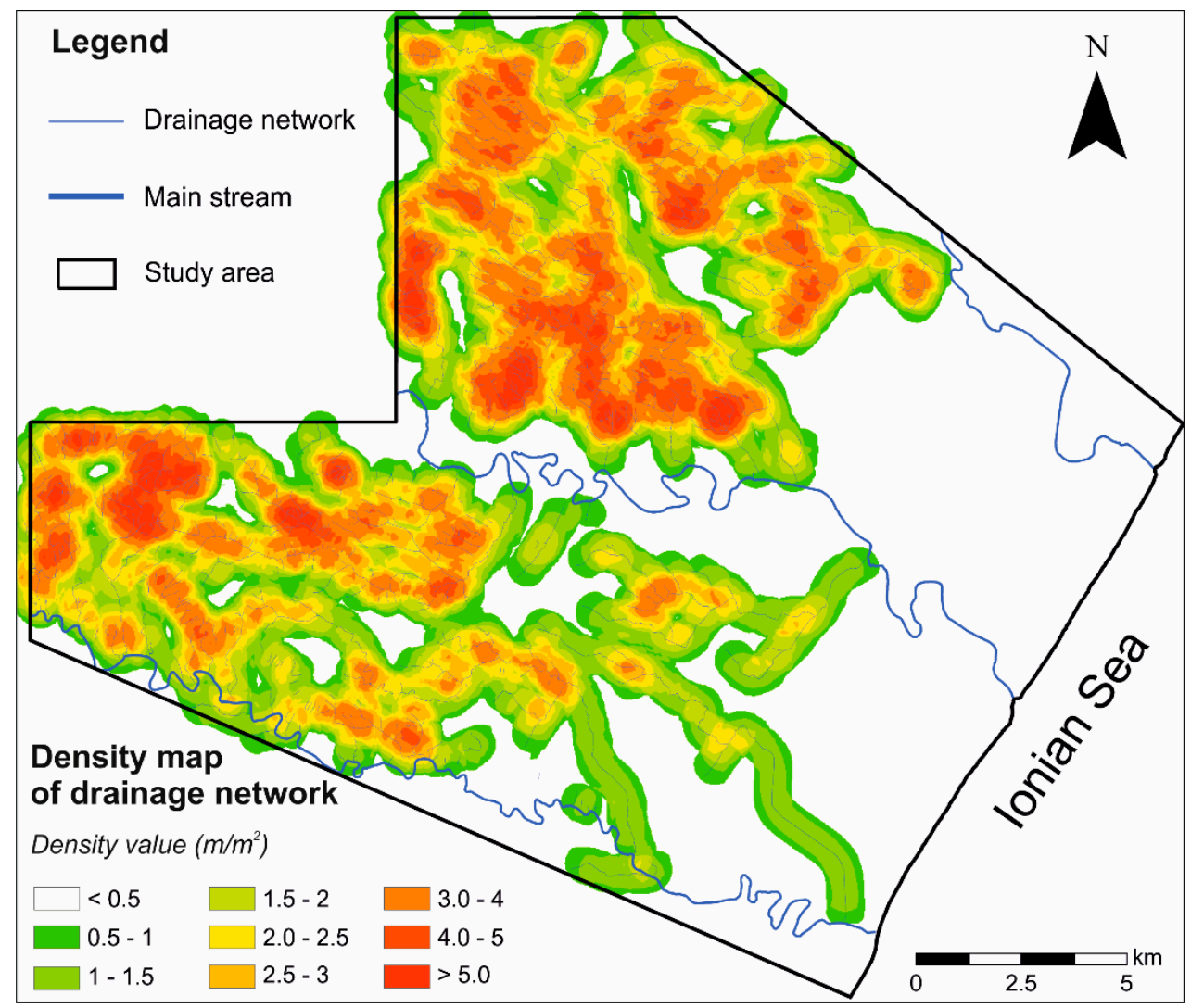

Figure 5. Drainage density map with a search radius of $500 \mathrm{~m}$.

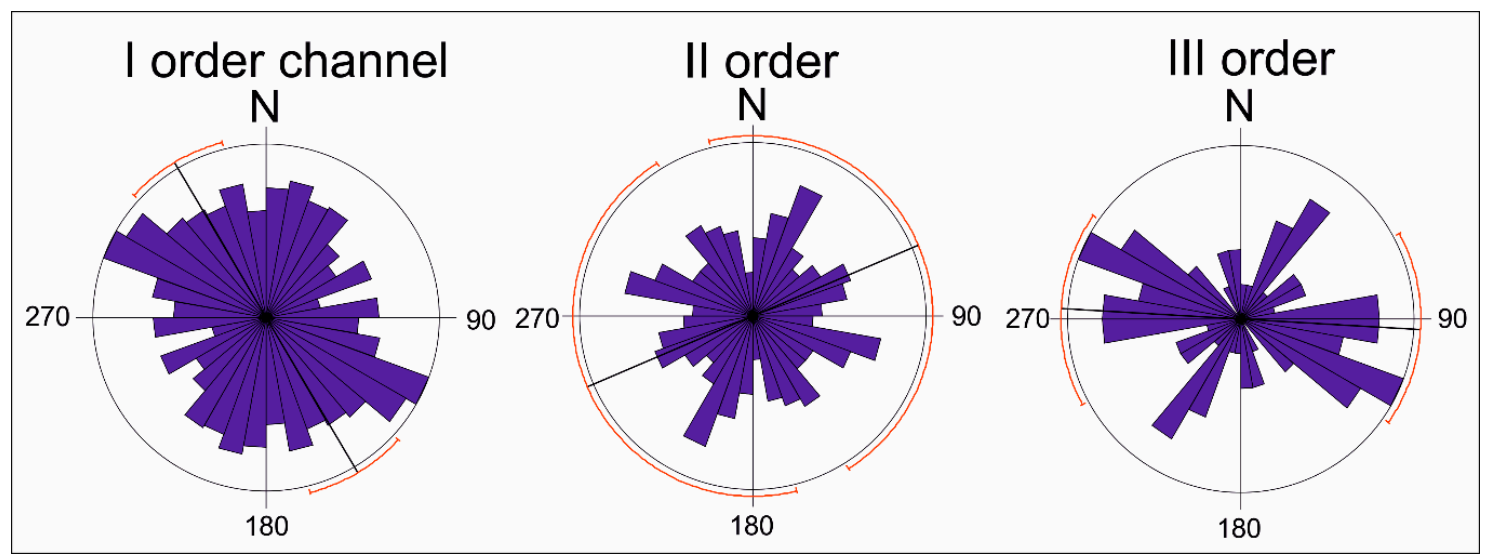

Figure 6. Frequency-weighted rose diagram of the I, II and III order channels of the study area. Black lines are the mean vector of the statistical population whereas the red arc circles indicate the $95 \%$ confidence interval of the azimuthal data.

Analysis of the relationships between orientation data and channel length (Figure 7a) did not highlight a clear influence of the extension of streams on the preferential orientation of the fluvial net. Length-weighted rose diagrams of Figure $7 \mathrm{~b}$ have been drawn through a segmentation of all the channels in reaches of $250 \mathrm{~m}$ and can furnish additional information about a possible tectonic 
control on the channels of different size and order. Maximum of I order channels is disposed along the $\mathrm{N} 100-\mathrm{N} 130^{\circ}$ trend whereas the II order streams show a preferential orientation according to the $\mathrm{N} 120-\mathrm{N} 160^{\circ}$ direction. Moreover, two main maxima (i.e., $\mathrm{N} 110-120^{\circ}$ and $\mathrm{N} 70-80^{\circ}$ can be recognized for the III order channels (Figure $7 \mathrm{~b}$ ).

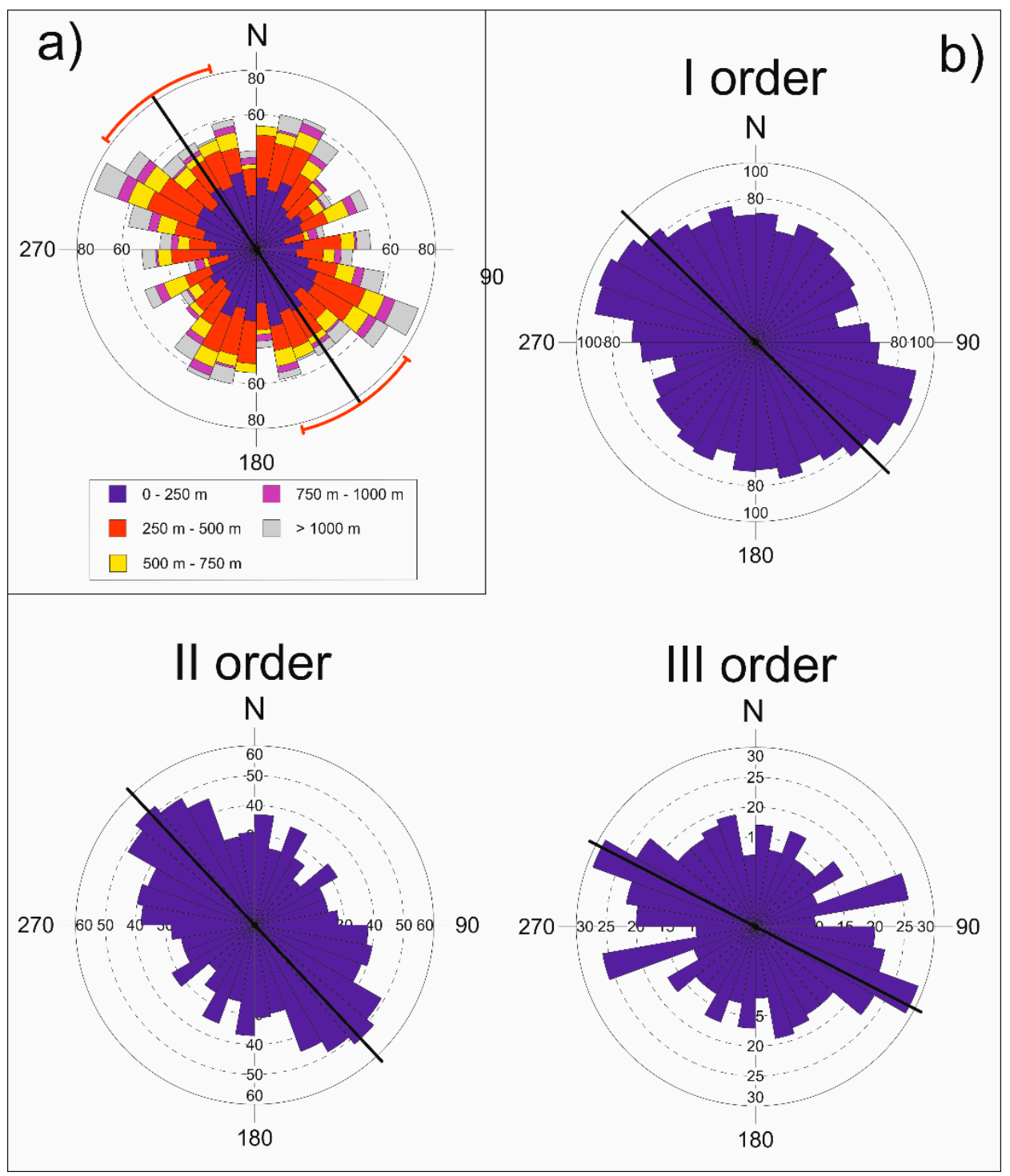

Figure 7. (a) Cumulative frequency-weighted rose diagram of I, II and III order channels (number of data: 962) of the study area grouped by stream length. (b) Length-weighted rose diagrams (segment of $250 \mathrm{~m}$ ) for the different hierarchical orders of the drainage network.

A comparison between stream orientation data and lithological features (Figure 8) highlights that fluvial channels cutting the Lower Pleistocene clay are featured by a high statistical noise and a moderate preferential orientation along the NNE-SSW trend. On the other hand, a well-developed trend of preferential orientation can be observed in the streams dissecting the marine terrace sequence: in fact, I and II order channels shows a significant maximum along the N $100-130^{\circ}$ orientation. $\mathrm{N} 90-120^{\circ}$ trend is clearly present in the III order channels together with the N $30-40^{\circ}$ and N $70-80^{\circ}$ direction (Figure 8). These azimuthal data indicate that the development of a rectangular pattern of the fluvial net is mainly controlled by the presence of outcrop of the marine terrace deposits. ESE-WNW (i.e., $\mathrm{N} 70-80^{\circ}$ ) and ENE-WSW orientation did not correspond with the parallel and transverse 
arrangement of the regional slope and this observation suggests the control of a roughly orthogonal "pervasive" fracture system on the orientation of channels developing in marine terrace deposits.

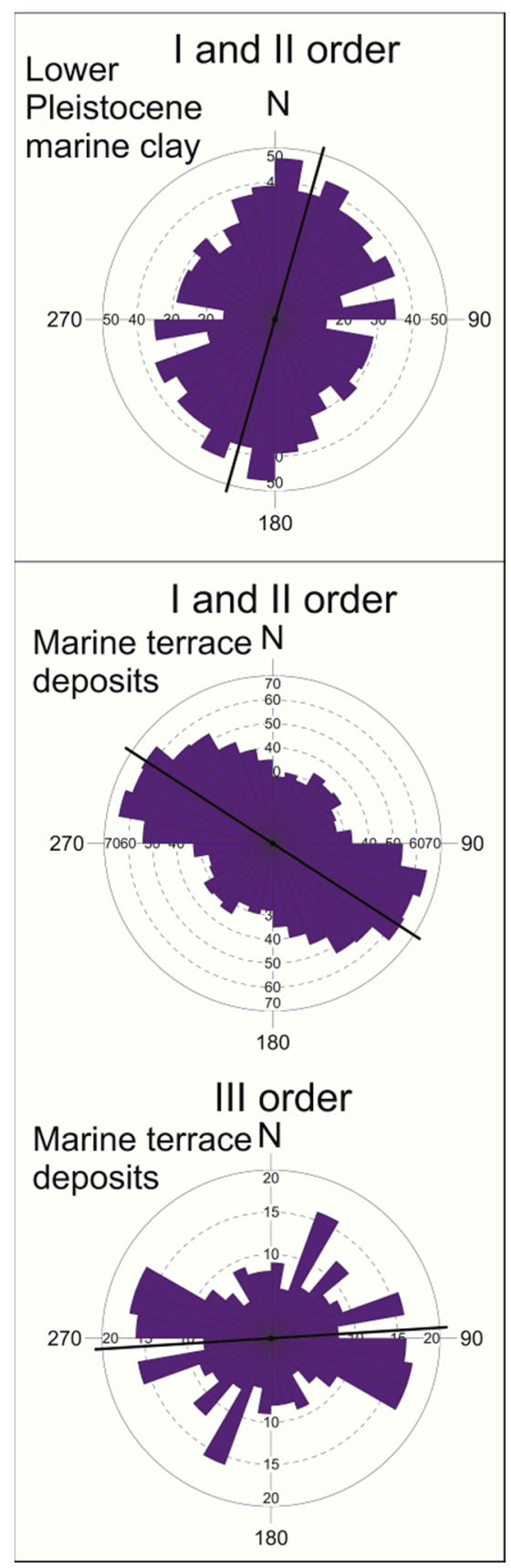

Figure 8. Stream orientation data (length-weighted analysis, segment of $250 \mathrm{~m}$ ) grouped by lithological type.

\subsection{River Profile Analysis}

Analysis of longitudinal river profiles of the bedrock-rivers is based on the stream power incision model $[43,45,48]$ and has been carried out to evaluate the channel response to eustaticand tectonic-induced processes. Most of the channel longitudinal profiles deviates from the typical equilibrium shape and there are featured by the presence of knickpoints and knickzones in the central reach of the river profiles. These knickpoints can be classified as slope-break knickpoint (sensu [45], see also [46]) and did not appear related to the lithological differences, suggesting a transient state of the fluvial net induced by tectonic perturbation or eustatic base-level variations. 
Figure 9 shows the spatial distribution of normalized channel steepness index (ksn) deriving by using a $\theta_{\text {ref }}=0.45$. Higher values of the ksn are mainly related to rectilinear segment of low and medium order channels. Moreover, highest values of ksn are frequently located downstream of channel reaches featured by anomalous confluences and right-angle elbows.

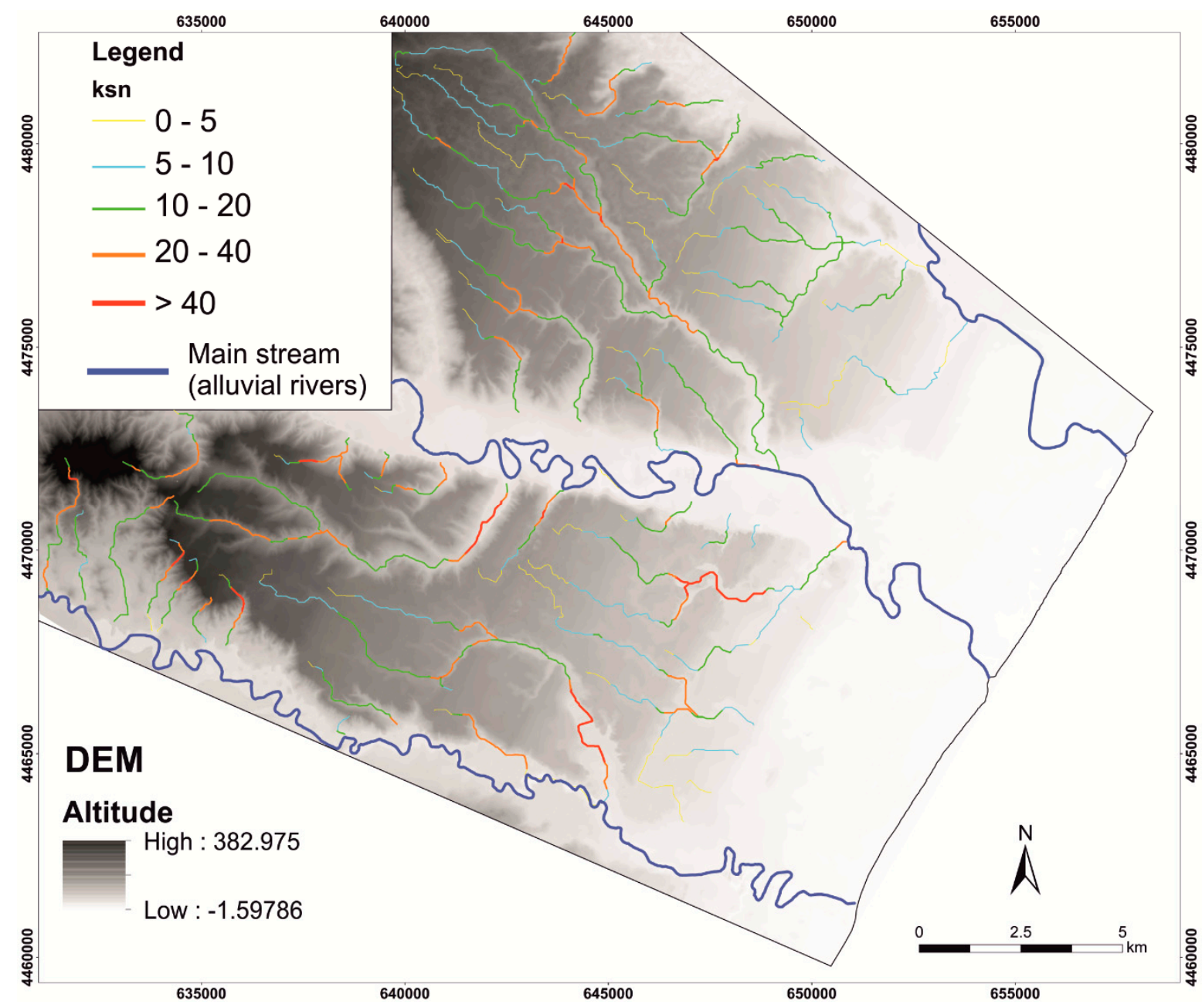

Figure 9. Ksn map of the study area.

In order to investigate the possible relationship between the degree of landscape dissection and tectonic control on stream orientation, a re-elaboration of channel azimuthal data against the concavity values of normalized river profiles has been done (Figure 10). I and II order channels show a well-developed trend of preferential orientation along the NW-SE and the contribution of transient (i.e., negative or null concavity value) and "graded" (i.e., positive value of C) appears substantially similar. On the other hand, the two roughly orthogonal trends of preferential orientation of the III order channels can be mainly attributed to the flow direction of streams with a convex and graded shape of the longitudinal profiles. 


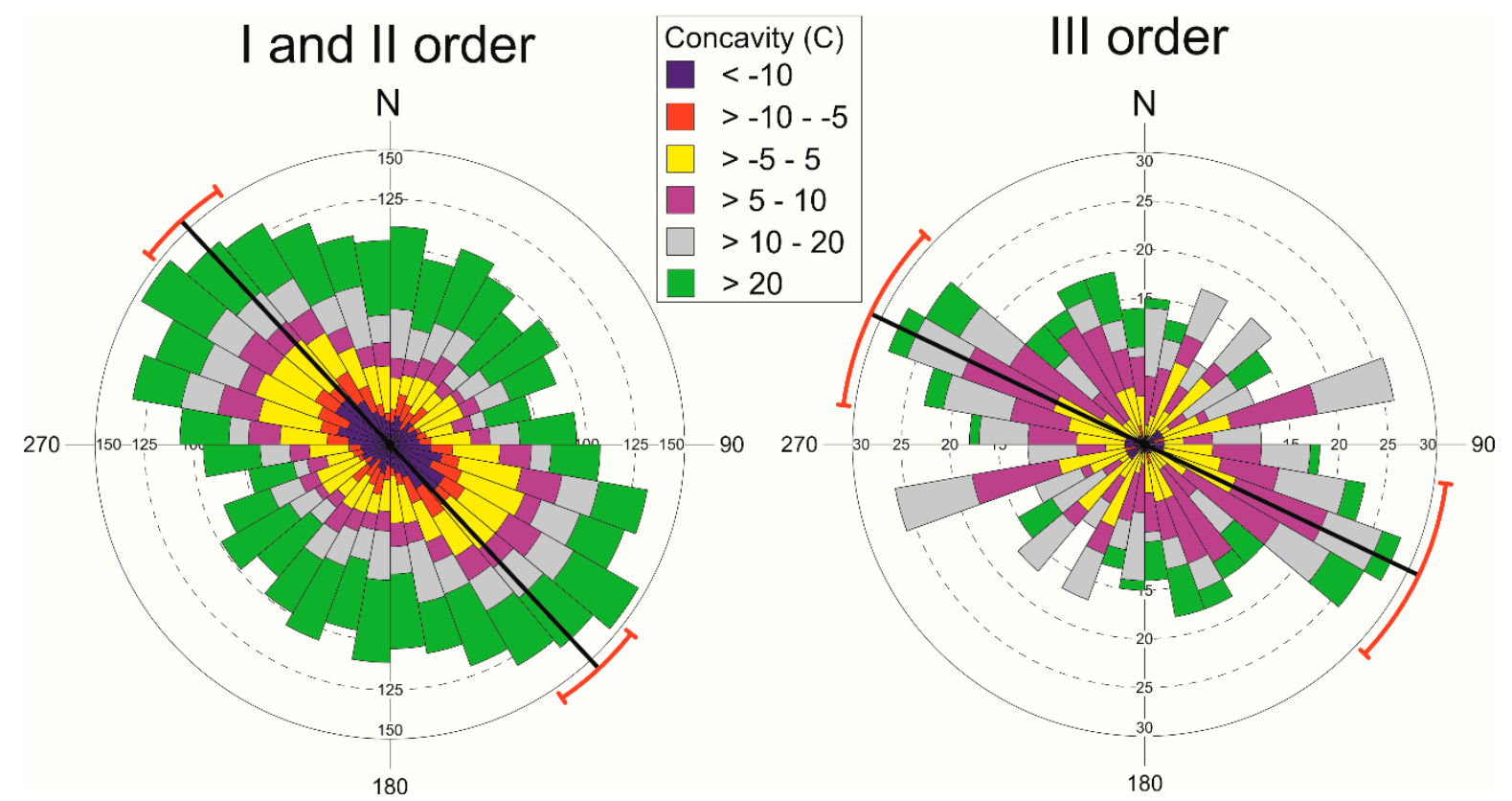

Figure 10. Length-weighted rose diagrams computed for different values of the concavity $(\mathrm{C})$ of river normalized profile.

\section{Discussion}

Integrated analysis of stream orientation data, plano-altimetric arrangement of knickpoints and knickzones, anomalous high values of the normalized channel steepness index (ksn) and morphotectonic evidences of drainage network anomalies allowed us to recognize a well-developed rectangular and tectonically-controlled pattern of drainage network in a coastal sector of the south-Italian foredeep. The drainage network shows some prominent features, which are typical of a strong tectonic control on fluvial channels evolution. In particular, preferential channel orientation and rectangular pattern along a NW-SE and NE-SW trend are mainly developed on the conglomerate of marine terrace sequence. Our results also highlight a regular spacing of the trellis-type drainage net and the diffuse presence of anomalies of smaller channels. These evidences are largely distributed on a large area (i.e., about $300 \mathrm{kmq}$ ), thus suggesting that the structural pattern is related to pervasive tectonic elements rather than to local-scale control factors such as the influence of single tectonic elements, landslide phenomena, or gravitative effects due to the fast deepening of main valley incisions. Then, this drainage network pattern is unusual in areas with lithological and morphostructural features similar to the study area and this kind of arrangement of the drainage net could be related to an orthogonal and pervasive fracture system. Specifically, the development of a pervasive orthogonal fracture system in the "conservative» lithology of the study area (i.e., conglomerates) could have controlled the orientation of the drainage net during the progressive emersion of the area, promoting the preferential development of ESE- and NNE-directed channels. The development of such a rectangular pattern is actually favoured by the presence of outcrop of marine terrace deposits (mainly cemented conglomerate and sandstone). A dendritic pattern is in fact otherwise present in the south-westernmost sectors of the study area, where clay deposits crop out. On a larger scale, the ESE-WNW and ENE-WSW orientations did not correspond to the parallel and transverse arrangement of the regional slope. The major rivers of the Ionian coastal belt, deeply cutting the marine terraces staircase, constitute a large-scale parallel pattern according to the regional dip of the foreland. They clearly show an antecedent character, since they represented the fluvial component of the coastal palaeoplain before the uplift sequence, as also testified by the diffuse presence of mid-Pleistocene alluvial deposits all along the Bradano foredeep [49], but their tributaries progressively developed on the emerging conglomerate plates due to a combination of pre-existing landforms driving (e.g., terrace 
scarps and inner edges), structural control (i.e., the pervasive orthogonal pattern), and retrogressive erosion mechanism promoted by uplift.

The occurrence of an orthogonal fracture system with orientation similar to those of the preferential orientation of minor channels can be attributed to a regional and recent bending of the foredeep, maybe related to the south-eastern migration of the thrust front of the Apennines chain-Calabrian Arc.

Although several Authors have argued a regional shortening and a contractional tectonic regime during Middle-Late Pleistocene times $[13,14]$ on the basis of the spatial and vertical arrangement of northern Calabria and Basilicata marine terrace staircase, the Holocene activity of the thrust front of the southern Apennines is still debated as well as its seismogenic potential.

Some Authors suggest that thrust activity has completely ceased [50] due to the involvement of the thick carbonate platform in the subduction processes. On the other hand, a regional shortening and contractional tectonics have been inferred by [13] in the Ionian coastal belt on the basis of the vertical and horizontal distribution of Middle to Late Pleistocene marine terrace staircase. These Authors recognized a NNE-ward converging geometry of all the palaeoshorelines and a cumulative amount of uplift that decreases toward the north-east. A similar interpretation can be derived by the interpretation of transverse swath profiles. The presence of a topographic bulge in the higher-order terraces in such profiles seems to confirm this interpretation. Also the pattern GPS velocities suggests evidence of thrust front activity and duplexing process [51]. In any case, our demonstration of a clear structural control on the drainage network pattern-the youngest geomorphic elements of the landscape-due to a fracture system probably produced by incipient folding, supports hypotheses of active tectonics.

\section{Concluding Remarks}

The right-angle pattern of minor fluvial net which cuts the terraced surfaces is largely diffused and regularly spaced in the Metaponto coastal area, suggesting a control by a pervasive orthogonal fracture system rather than by isolated faults and/or master joints. Such a structural pattern and the arrangement of the terraces slope don't match very well with the tectonic features associated to a vertical uplift motion. Fractures were produced and preserved into the brittle caprock of the terraces, made by conglomerate, and exerted their control on the minor fluvial channels that progressively deepened into the underlying Pleistocene clay and sand, but they are not much represented in these soft rocks. Since a similar pervasive and orthogonal fracture pattern is actually generated by gentle folding of rocks, the development of the Ionian hydrographic networks could be attributed to a general-maybe still active-bending of the foredeep area due to the propagation toward east-northeast and south-east, respectively, of blind thrusting of the Campania-Lucania and Calabrian segments of the southern Apennines chain.

Author Contributions: Conceptualization, D.G., M.S., and S.I.G.; Methodology, D.G., M.S., and S.I.G.; Software, D.G.; Validation, D.G. and M.S.; Formal Analysis, D.G.; Investigation, D.G. and M.S.; Data Curation, D.G. and M.S.; Writing-Original Draft Preparation, D.G.; Writing-Review \& Editing, D.G. and M.S. Supervision, D.G., M.S., and S.I.G.

Acknowledgments: The authors would like to thank two anonymous reviewers for their useful and constructive comments.

Conflicts of Interest: The authors declare no conflict of interest.

\section{References}

1. Demoulin, A.; Anne, M.; Alexander, W. Fluvial archives, a valuable record of vertical crustal deformation. Quat. Sci. Rev. 2017, 166, 10-37. [CrossRef]

2. Bahrami, S. Analyzing the drainage system anomaly of Zagros basins: Implications for active tectonics. Tectonophysics 2013, 608, 914-928. [CrossRef]

3. Boulton, S.J.; Stokes, M.; Mather, A.E. Transient fluvial incision as an indicator of active faulting and Plio-Quaternary uplift of the Moroccan High Atlas. Tectonophysics 2014, 633, 16-33. [CrossRef] 
4. Delcaillau, B. Geomorphic response to growing fault-related folds: Example from the foothills of central Taiwan. Geodin. Acta 2001, 14, 265-287. [CrossRef]

5. Demoulin, A.; Altin, T.B.; Beckers, A. Morphometric age estimate of the last phase of accelerated uplift in the Kazdag area (Biga Peninsula, NW Turkey). Tectonophysics 2013, 608, 1380-1393. [CrossRef]

6. Gioia, D.; Schiattarella, M.; Mattei, M.; Nico, G. Quantitative morphotectonics of the Pliocene to Quaternary Auletta basin, southern Italy. Geomorphology 2011, 134, 326-343. [CrossRef]

7. Gioia, D.; Schiattarella, M. An alternative method of azimuthal data analysis to improve the study of relationships between tectonics and drainage networks: Examples from southern Italy. Z. Geomorphol. 2010, 54, 225-241. [CrossRef]

8. Deffontaines, B.; Chorowicz, J. Principles of drainage basin analysis from multisource data: Application to the structural analysis of the Zaire Basin. Tectonophysics 1991, 194, 237-263. [CrossRef]

9. Beneduce, P.; Festa, V.; Francioso, R.; Schiattarella, M.; Tropeano, M. Conflicting drainage patterns in the Matera Horst Area, southern Italy. Phys. Chem. Earth 2004, 29, 717-724. [CrossRef]

10. Stokes, M.; Mather, A.E.; Belfoul, A.; Farik, F. Active and passive tectonic controls for transverse drainage and river gorge development in a collisional mountain belt (Dades Gorges, High Atlas Mountains, Morocco). Geomorphology 2008, 102, 2-20. [CrossRef]

11. Tropeano, M.; Cilumbriello, A.; Sabato, L.; Gallicchio, S.; Grippa, A.; Longhitano, S.G.; Biancacd, M.; Gallipolid, R.M.; Mucciarellic, M.; Spilotro, G. Surface and subsurface of the Metaponto Coastal Plain (Gulf of Taranto-Southern Italy): Present-day-vs LGM-landscape. Geomorphology 2013, 203, 115-131. [CrossRef]

12. Brückner, H. Marine Terrassen in Süditalien. Eine quartärmorphologische Studie über das Küstentiefland von; Universität Düsseldorf: Düsseldorf, Germany, 1980.

13. Caputo, R.; Bianca, M.; D'Onofrio, R. Ionian marine terraces of southern Italy: Insights into the Quaternary tectonic evolution of the area. Tectonics 2010, 29. [CrossRef]

14. Santoro, E.; Ferranti, L.; Burrato, P.; Mazzella, M.E.; Monaco, C. Deformed Pleistocene marine terraces along the Ionian Sea margin of southern Italy: Unveiling blind fault-related folds contribution to coastal uplift. Tectonics 2013, 32, 737-762. [CrossRef]

15. Westaway, R.; Bridgland, D. Late Cenozoic uplift of southern Italy deduced from fluvial and marine sediments: Coupling between surface processes and lower-crustal flow. Quat. Int. 2007, 175, 86-124. [CrossRef]

16. Belluomini, G.; Caldara, M.; Casini, C.; Cerasoli, M.; Manfra, L.; Mastronuzzi, G.; Palmentolab, G.; Sansob, P.; Tuccimeief, P.; Vesica, P.L. The age of Late Pleistocene shorelines and tectonic activity of Taranto area, Southern Italy. Quat. Sci. Rev. 2002, 21, 525-547. [CrossRef]

17. Bentivenga, M.; Coltorti, M.; Prosser, G.; Tavarnelli, E. A new interpretation of terraces in the Taranto Gulf: The role of extensional faulting. Geomorphology 2004, 60, 383-402. [CrossRef]

18. Cucci, L.; Cinti, F.R. Regional uplift and local tectonic deformation recorded by the Quaternary marine terraces on the Ionian coast of northern Calabria (Southern Italy). Tectonophysics 1998, 292, 67-83. [CrossRef]

19. Caputo, R.; Bianca, M. Comment on "Late Cenozoic uplift of southern Italy deduced from fluvial and marine sediments: Coupling between surface processes and lower-crustal flow" by Westaway R. and Bridgland D. (Quaternary International 175, 86-124). Quat. Int. 2009, 204, 98-102. [CrossRef]

20. Westaway, R.; Bridgland, D. Reply to comment by Riccardo Caputo and Marcello Bianca on "Late Cenozoic uplift of southern Italy deduced from fluvial and marine sediments: Coupling between surface processes and lower-crustal flow" by Rob Westaway and David Bridgland; improved uplift modelling of the Gulf of Taranto marine terraces. Quat. Int. 2009, 210, 102-109.

21. Tropeano, M.; Sabato, L.; Pieri, P. Filling and cannibalization of a foredeep: The Bradanic Trough, Southern Italy. Geol. Soc. Lond. Spec. Publ. 2002, 191, 55-79. [CrossRef]

22. Cilumbriello, A.; Sabato, L.; Tropeano, M.; Gallicchio, S.; Grippa, A.; Maiorano, P.; Mateu-vicens, G.; Rossi, C.A.; Spilotro, G.; Calcagnile, L.; et al. Sedimentology, Stratigraphic Architecture and Preliminary Hydrostratigraphy of the Metaponto Coastal-Plain Subsurface (Southern Italy). Available online: http: / / www.isprambiente.gov.it/files/pubblicazioni/periodicitecnici/memorie/memoriexc/90cilumbriello.pdf (accessed on 21 August 2018).

23. Gioia, D.; Bavusi, M.; Di Leo, P.; Giammatteo, T.; Schiattarella, M. A geoarchaeological study of the metaponto coastal belt, southern Italy, based on geomorphological mapping and gis-supported classification of landforms. Geogr. Fis. Din. Quat. 2016, 39, 137-148. 
24. Leo, P.D.; Bavusi, M.; Corrado, G.; Danese, M.; Giammatteo, T.; Gioia, D.; Marcello, S. Ancient settlement dynamics and predictive archaeological models for the metapontum coastal area in basilicata, southern Italy: From Geomorphological survey to spatial analysis. J. Coast. Conserv. 2017, 2, 1-13.

25. De Musso, N.M.; Capolongo, D.; Refice, A.; Lovergine, F.P.; D'Addabbo, A.; Pennetta, L. Spatial evolution of the December 2013 Metaponto plain (Basilicata, Italy) flood event using multi-source and high-resolution remotely sensed data. J. Maps 2018, 14, 219-229. [CrossRef]

26. Centro_Cartografico_Dipartimentale_Regione_Basilicata. $\quad 5 \mathrm{~m}$ DEM. Available online: http: / /rsdi.regione.basilicata.it/Catalogo/srv/ita/search?hl=ita/\#_\T1 \textbar\{\}r_basili:9EE9C09A-7091D8A2-A41D-F28191B86C4F (accessed on 21 August 2018).

27. Boulton, S.J.; Stokes, M. Which DEM is best for analyzing fluvial landscape development in mountainous terrains? Geomorphology 2018, 310, 168-187. [CrossRef]

28. Delcaillau, B.; Deffontaines, B.; Floissac, L.; Angelier, J.; Deramond, J.; Souquet, P.; Chu, H.T.; Lee, J.F. Morphotectonic evidence from lateral propagation of an active frontal fold; pakuashan anticline, foothills of taiwan. Geomorphology 1998, 24, 263-290. [CrossRef]

29. Capolongo, D.; Cecaro, G.; Giano, S.I.; Lazzari, M.; Schiattarella, M. Structural control on drainage network of the south-western side of the agri river upper valley (southern Apennines, Italy). Supplementi Di Geogr. Fis. Din. Quat. 2005, 28, 169-180.

30. Wu, L.; Xiao, A.; Yang, S. Impact of wind erosion on detecting active tectonics from geomorphic indexes in extremely arid areas: A case study from the hero range, qaidam basin, NW China. Geomorphology 2014, 224, 39-54. [CrossRef]

31. Calzolari, G.; Della Seta, M.; Rossetti, F.; Nozaem, R.; Vignaroli, G.; Cosentino, D.; Faccenna, C. Geomorphic signal of active faulting at the northern edge of lut block: Insights on the kinematic scenario of central Iran. Tectonics 2016, 35, 76-102. [CrossRef]

32. Ribolini, A.; Spagnolo, M. Drainage network geometry versus tectonics in the argentera massif (French-Italian Alps). Geomorphology 2018, 93, 253-266. [CrossRef]

33. Pérez-Peña, J.V.; Al-Awabdeh, M.; Azañón, J.M.; Galve, J.P.; Booth-Rea, G.; Notti, D. SwathProfiler and NProfiler: Two new ArcGIS add-ins for the automatic extraction of swath and normalized river profiles. Comput. Geosci. 2016, 104, 135-150. [CrossRef]

34. Strahler, A.N. Quantitative analysis of watershed geomorphology. Eos Trans. Am. Geophy. Union 1957, 38, 913-920. [CrossRef]

35. Gioia, D.; Gallicchio, S.; Moretti, M.; Schiattarella, M. Landscape response to tectonic and climatic forcing in the foredeep of the southern Apennines, Italy: Insights from quaternary stratigraphy, Quantitative geomorphic analysis, and denudation rate proxies. Earth Surf. Proc. Land. 2014, 39, 814-835. [CrossRef]

36. Whittaker, A.C.; Boulton, S.J. Tectonic and climatic controls on knickpoint retreat rates and landscape response times. J. Geophy. Res. Earth Surf. 2012, 117. [CrossRef]

37. Wei, Z.; Bi, L.; Xu, Y.; He, H. Evaluating knickpoint recession along an active fault for paleoseismological analysis: The Huoshan Piedmont, Eastern China. Geomorphology 2015, 235, 63-76. [CrossRef]

38. Cyr, A.J.; Granger, D.E.; Olivetti, V.; Molin, P. Quantifying rock uplift rates using channel steepness and cosmogenic nuclide-determined erosion rates: Examples from northern and southern Italy. Lithoshere 2010, 2 , 188-198. [CrossRef]

39. Troiani, F.; Seta, M.D. The use of the stream Length-Gradient index in morphotectonic analysis of small catchments: A case study from central Italy. Geomorphology 2008, 102, 159-168. [CrossRef]

40. Kirby, E.; Whipple, K. Quantifying differential rock-uplift rates via stream profile analysis. Geology 2001, 29, 415-418. [CrossRef]

41. Demoulin, A. Basin and river profile morphometry: A new index with a high potential for relative dating of tectonic uplift. Geomorphology 2011, 126, 97-107. [CrossRef]

42. Pérez-Peña, J.V.; Azañón, J.M.; Azor, A.; Delgado, J.; González-Lodeiro, F. Spatial analysis of stream power using GIS: SLk anomaly maps. Ear. Surf. Proc. Land. 2010, 34, 16-25. [CrossRef]

43. Whipple, K.X.; Tucker, G.E. Dynamics of the stream-power river incision model: Implications for height limits of mountain ranges, landscape response timescales, and research needs. J. Geophys. Res. Solid Earth 1999, 104, 17661-17674. [CrossRef] 
44. Snyder, N.P.; Whipple, K.X.; Tucker, G.E.; Merritts, D.J. Landscape response to tectonic forcing: Digital elevation model analysis of stream profiles in the Mendocino triple junction region, northern California. Geol. Soc. Am. Bull. 2000, 112, 1250-1263. [CrossRef]

45. Wobus, C.; Whipple, K.X.; Kirby, E.; Snyder, N.; Johnson, J.; Spyropolou, K.; Crosby, B.; Willett, S.D. Tectonics from Topography: Procedures, Promise, and Pitfalls. Available online: https://asu.pure.elsevier.com/en/ publications/tectonics-from-topography-procedures-promise-and-pitfalls (accessed on 21 August 2018).

46. Kirby, E.; Whipple, K.X. Expression of active tectonics in erosional landscapes. J. Struct. Geol. 2012, 44, 54-75. [CrossRef]

47. Demoulin, A. Testing the tectonic significance of some parameters of longitudinal river profiles: The case of the Ardenne (Belgium, NW Europe). Geomorphology 1988, 24, 189-208. [CrossRef]

48. Whipple, K.X. Bedrock Rivers and the geomorphology of active orogens. Annu. Rev. Earth Planet. Sci. 2004, 32, 151-185. [CrossRef]

49. Corrado, G.; Leo, P.D.; Giannandrea, P.; Schiattarella, M. Constraints on the dispersal of Mt. Vulture pyroclastic products: Implications to mid-Pleistocene climate conditions in the foredeep domain of southern Italy. Geomorphologie 2017, 23, 171-182. [CrossRef]

50. Patacca, E.; Scandone, P. Anatomy of an Orogen: The Apennines and Adjacent Mediterranean Basins; Springer: Dordrecht, The Netherlands, 2001; pp. 401-440.

51. Ferranti, L.; Oldow, J.S.; D’Argenio, B.; Catalano, R.; Lewis, D.; Marsella, E.; Avellone, G.; Maschio, L.; Pappone, G.; Pepe, F.; et al. Active deformation in southern Italy, Sicily and southern Sardinia from GPS velocities of the Peri-Tyrrhenian Geodetic Array (PTGA). Boll. Soc. Geol. Ital. 2008, 127, 299-316.

(C) 2018 by the authors. Licensee MDPI, Basel, Switzerland. This article is an open access article distributed under the terms and conditions of the Creative Commons Attribution (CC BY) license (http:/ / creativecommons.org/licenses/by/4.0/). 